\title{
Article
}

\section{Do Consumers Value Environmental Innovation in Product?}

\author{
Cristina Aibar-Guzmán ${ }^{1}$ and Francisco M. Somohano-Rodríguez ${ }^{2, *(D)}$ \\ 1 Facultad de Ciencias Económicas y Empresariales, University of Santiago de Compostela, \\ 15782 Santiago de Compostela, Spain; cristina.aibar@usc.es \\ 2 Facultad de Ciencias Económicas y Empresariales, University of Cantabria, 39005 Santander, Spain \\ * Correspondence: fm.somohano@unican.es
}

\section{check for}

updates

Citation: Aibar-Guzmán, Cristina, and Francisco M. SomohanoRodríguez. 2021. Do Consumers

Value Environmental Innovation in Product?. Administrative Sciences 11: 33. https://doi.org/10.3390/ admsci11010033

Received: 26 February 2021

Accepted: 18 March 2021

Published: 22 March 2021

Publisher's Note: MDPI stays neutral with regard to jurisdictional claims in published maps and institutional affiliations.

Copyright: (c) 2021 by the authors. Licensee MDPI, Basel, Switzerland. This article is an open access article distributed under the terms and conditions of the Creative Commons Attribution (CC BY) license (https:// creativecommons.org/licenses/by/ $4.0 /)$.

\begin{abstract}
Customers are considered to be major stakeholders whose demands and preferences have a strong influence on corporate strategies. In this sense, increased consumer environmental awareness has led to a growing demand for environmentally friendly products which, in turn, has compelled firms to adopt innovative forms of integrating environmental protection into product development and production processes. Nevertheless, an "attitude-behavior gap" has been witnessed, which implies that consumers' environmental attitudes do not always translate into an actual ecologically compatible purchasing behavior and, consequently, eco-product innovations will not necessarily entail a positive economic impact for companies. This paper aims to analyze if the companies that invest in eco-product innovation are valued by consumers, showing higher growth. Specifically, we propose that eco-product innovation has a positive effect on a firm's sales growth. Additionally, we aim to analyze the consumers' preferences in relation to eco-product innovations considering two alternative approaches that companies can follow in this respect: eco-design and products with ecological use. The results obtained for an unbalanced sample of 5391 international companies corresponding to the period 2002-2017 (51,666 observations) show that proactive environmental innovation strategies are positively valued by consumers, having a positive impact on the companies' sales growth. Furthermore, consumers show a greater preference for environmental innovations in eco-design than for products with ecological use.
\end{abstract}

Keywords: customer purchasing behavior; environmentally friendly products; eco-product innovation; eco-design

\section{Introduction}

Over the last decades, consumer environmental awareness has risen significantly (Sehgal and Singh 2010; Mylan et al. 2015; Hojnik and Ruzzier 2016) leading to a shift in customer buying criteria toward higher attention to environmental and social issues (Laroche et al. 2001). As a result, besides price and quality preferences, consumer choices are influenced by environmental and ethical considerations (Sehgal and Singh 2010), which has translated into a growing demand for environmentally friendly products and services (Brosdahl and Carpenter 2010) and, conversely, decreasing demand for those products and services with a questionable social and environmental impact (Kassinis and Soteriou 2003).

These changing consumer demands force companies to modify their products and processes looking for innovative ways to reduce or eliminate their adverse effects on the natural environment in order to avoid losing their customer base (Hojnik and Ruzzier 2016). In this regard, most environmentally friendly products are based on technological innovations in their development process aimed at reducing the negative environmental impacts throughout their whole life cycle (Kesidou and Demirel 2012; Cheng et al. 2014), so that they are often considered innovations in the market (Shim et al. 2018). In this sense, prior literature has identified customer pressure as a key driver of eco-innovation (Triebswetter and Wackerbauer 2004; Doran and Ryan 2012; Sarkis et al. 2010; Zeng et al. 2011; Guoyou et al. 2013; Hojnik and Ruzzier 2016). 
Nevertheless, some authors have identified an "attitude-behavior gap" (Wong et al. 1996) which implies that consumers' environmental attitudes do not always translate into an actual ecologically compatible purchasing behavior (Brosdahl and Carpenter 2010; Royne et al. 2011). This gap has been witnessed over different product categories (Shim et al. 2018) and can be attributed to several motives, such as laziness (Blake 1999), consumer confusion due to greenwashing cases (Carrete et al. 2012; Durif et al. 2010), doubts about product effectiveness (Luchs et al. 2010) or superiority (Arena et al. 2018), and customers' price consciousness (Shim et al. 2018), i.e., given that, in comparison with traditional products, environmentally friendly products often have a price premium (Mintel 2009), not all consumers are willing to pay more for them (Haws et al. 2014; Doran and Ryan 2012). Consequently, eco-product innovations will not necessarily entail a positive economic impact on the company (García-Sánchez et al. 2020a). This would imply that companies considering eco-innovation can face a "prisoners' dilemma", eco-innovation being the losing strategy (Zhang et al. 2011).

With these premises, based on stakeholders theory, the aim of this paper is to analyze whether the companies that invest in eco-product innovation are more valued by consumers, showing greater business growth. More specifically, we intend to answer the following questions: do consumers value environmental innovation? What are consumers' preferences regarding environmental innovation in product? The results obtained for an unbalanced sample of 5391 international companies corresponding to the period 2002-2017 (51,666 observations) show that proactive environmental innovation strategies are positively valued by consumers, having a positive impact on sales growth. Furthermore, consumers show a greater preference for environmental innovations in eco-design than for products with ecological use.

Our research contributes to previous literature in several aspects. Firstly, our findings extend and reinforce prior research on consumer behavior in relation to eco-product innovation. Most prior studies on this issue have been based on subjective data obtained through surveys (Cheng and Shiu 2012). However, as noted by Brosdahl and Carpenter (2010) and Shim et al. (2018), it is unclear that consumers' stated concern for environment protection translates into actual purchase behavior of environmentally friendly products, given that they may feel social pressure to express a "politically correct" attitude that, in fact, does not correspond to their actual behavior. In this sense, sales growth more objectively reflects consumer purchase behavior. Thus, by showing that the commercialization of environmentally friendly products has a positive effect on sales growth, our findings demonstrate consumers' preference for this type of eco-innovations. Hence, the results indicate that the product's environmental attributes constitute a differentiator factor that attracts consumers, which is reflected in their purchasing choices, thereby positively affecting sales.

Nevertheless, in our opinion, the main contribution and novelty of our study resides in the split between two different approaches of eco-product innovations: eco-design and eco-use, which allows us to advance the understanding of consumer purchase behavior in relation to environmentally friendly products. In this regard, by providing empirical evidence of the effect on sales growth of each alternative (i.e., eco-design and products with ecological use) our study provides novel empirical evidence about the preferences of consumers in relation to the different types of ecological products, indicating which are most valued by them. Furthermore, given that few studies have analyzed the economic return of eco-design (Plouffe et al. 2011), our study provides new evidence on this issue.

Secondly, we add to the understanding of the economic impact of environmental innovations by showing the effect of eco-product innovations on sales growth. Although the contribution of environmental innovations to business performance has been extensively analyzed (Przychodzen and Przychodzen 2015; Oh et al. 2020), prior research obtained no conclusive results (Hojnik et al. 2018). A possible explanation could be the use of different proxies of firm performance (e.g., ROI, profitability, operating profit). In this sense, as Alos-Simo et al. (2020) point out, these measures may be strongly linked to financial data, which can disrupt the relationship, and, consequently, they do not provide a solid measure of the impact of eco-innovation on firm performance. We use sales growth to quantify the economic impact of eco-product innovations, a measure the reflects "the main link between eco-innovation and 
(firm) growth [ ... ] by derived demand-pull dynamics" (Colombelli et al. 2019) and has been used in prior literature to quantify the economic benefit of environmentally friendly products (Oh et al. 2020).

However, while prior studies have been focused on a single country (Cheng et al. 2014; Hojnik and Ruzzier 2016; Oh et al. 2020; Alos-Simo et al. 2020), a reduced number of countries (Plouffe et al. 2011; Colombelli et al. 2019) or a specific sector (Kim et al. 2019), we adopt a broader approach encompassing several countries and activity sectors. This allows us to analyze data from 5931 international companies, which contributes to the generalization of the findings. Additionally, we consider a long analysis period (2002-2017), which makes our results more robust.

This paper is structured as follows: after this introduction, the development of the research hypotheses on the effect of eco-product innovations on sales growth is presented in the following section. Section 3 describes the empirical framework of the study (sample, variables, models, and analysis techniques), whereas Section 4 presents and discusses the main findings. Finally, Section 5 summarizes the conclusions and the main theoretical and practical implications of the study.

\section{Theoretical Background and Hypotheses Development}

\subsection{Corporate Social Responsibility and Proactive Environmental Strategies}

Stakeholders theory focuses its attention on the demands of the firms' stakeholders (e.g., customers, shareholders, employees, environmental groups, and the government). In this regard, the capacity of stakeholders to impose their demands is related to their actual influence on the firm ( $\mathrm{O}^{\prime}$ Donovan 2002). Nowadays, companies face increasing social and political pressures for reducing the adverse environmental impacts of their activities and improving their environmental performance (Demirel and Kesidou 2019). As a result, they respond to these pressures by seeking to reduce the impacts of their operations on the natural environment (da Silva Monteiro and Aibar-Guzmán 2009).

However, such an environmental orientation can be simply the result of a compliancebased strategy (Roome 1992) through which companies limit themselves to adopt reactive measures of compliance to respond to external pressures from both legislation and stakeholders in order to avoid economic and/or social costs (Bennett and James 1998). In contrast to this reactive positioning, other firms assume a proactive position seeking to be ahead of such pressures (da Silva Monteiro and Aibar-Guzmán 2009) as a way of differentiating themselves from competitors in order to improve their competitive position. Instead of considering environmental protection as a sunken cost that they have to assume, these companies acknowledge the potential benefits of an improved environmental performance integrating environmental issues into their strategies (da Silva Monteiro and Aibar-Guzmán 2009).

As a result, firms are increasingly socially and environmentally oriented and corporate social responsibility (CSR) has become "a significant business practice globally" (Kraus et al. 2020). There is a relationship between CSR practices and innovation (Gallego-Álvarez et al. 2011) so that CSR positively affect product innovation (Zhou et al. 2020). Thus, to the extent that companies are able to align CSR and innovation strategies, they could obtain strategic synergies (Zhou et al. 2020).

Environmental innovation is considered a way to achieve an enhanced environmental performance (Carfora et al. 2021) attracting the growing attention of researchers interested in knowing its drivers and outcomes (Cancino et al. 2018; Pacheco et al. 2018). In this sense, stakeholder pressures have been identified as the main driver of environmental innovation (García-Sánchez et al. 2020b). In this sense, environmentally proactive firms seek to anticipate the future evolution of environmental legislation, consumers' demands, and competitors' actions in regard to the products' ecological footprint (Bennett and James 1998; da Silva Monteiro and Aibar-Guzmán 2009; Triebswetter and Wackerbauer 2008; Albino et al. 2009) through environmental innovation (Guoyou et al. 2013; Demirel and Kesidou 2019; Sdrolia and Zarotiadis 2019; García-Sánchez et al. 2020b). 
Prior literature has stressed the importance that a firm considers the demands and needs of different stakeholder groups (e.g., customers, shareholders, employees, environmental groups, and the government) when defining its CSR policies and environmental strategies (Tang et al. 2012; Al-Shammari et al. 2019; Scheidler et al. 2019). In this regard, according to del Val Segarra Oña et al. (2013), the stronger is the stakeholders' influence on environmental decisions, the greater will be the firm's proactive environmental orientation.

\subsection{The Effect of Eco-Product Innovations on Sales Growth}

Given that customer demand is critical for company survival (Chiou et al. 2011), customers are considered to be major stakeholders whose demands and preferences have a strong influence on these corporate proactive strategies. In this sense, customer pressure has been identified as a key driving force of eco-innovation (Doran and Ryan 2012; Hojnik and Ruzzier 2016; Guoyou et al. 2013; Del Río Pablo and Könnölä 2010). Indeed, as indicated earlier, increased consumer environmental awareness has led to a growing demand for environmentally friendly products (Sehgal and Singh 2010; Brosdahl and Carpenter 2010; Doran and Ryan 2012; Hojnik et al. 2018), which, in turn, has compelled firms to adopt innovative forms of integrating environmental protection into product development and production processes (Doran and Ryan 2012; Guoyou et al. 2013; Hojnik and Ruzzier 2016). These companies use products' environmental features as a differentiating tool which allows them to obtain competitive advantages (Reinhardt 1998; Chen and Chang 2012).

To the extent that a firm is able of satisfying customer demands regarding environmental responsibility, it will be able to increase its market share, accessing to new markets or market segments where consumers are more environmentally conscious and increasing its sales volume in current markets due to an improved image/reputation (Lee and Min 2015; Kim et al. 2019; Colombelli et al. 2019; Oh et al. 2020). Furthermore, given that environmentally friendly products often entail a price premium (Mintel 2009), eco-product innovations also have a positive effect on revenues (Plouffe et al. 2011; Alos-Simo et al. 2020). Accordingly, these proactive environmental strategies would allow companies to enhance their competitive advantages and improve their environmental and financial performance with a "win-win logic" (Porter and Linde 1995; Reinhardt 1998).

However, the "attitude-behavior gap" phenomenon evidenced in the case of environmentally friendly products (Wong et al. 1996; Brosdahl and Carpenter 2010; Shim et al. 2018) implies that consumers do not buy such products with the expected regularity (Gleim et al. 2013) and, consequently, their potential positive impact on sales and market share may be questioned. In this sense, although most studies document a positive effect of eco-product innovation on market share and sales growth (Cheng et al. 2014; Colombelli et al. 2019; Kim et al. 2019; Oh et al. 2020), other authors found that such an effect exists only in terms of market share but not in the case of sales growth (Menguc and Ozanne 2005), or only for some industries but not for other (Alos-Simo et al. 2020).

Accordingly, in order to determine if really environmental innovations in products are valued by consumers and this interest translates into a positive effect on firm sales, the following hypothesis is stated:

Hypothesis 1 (H1). Eco-product innovation is positively associated with sales growth.

\subsection{Consumers' Preferences about Eco-Friendly Products}

Although environmental innovations encompass "all forms of innovation that reduce environmental impacts [ ... ] through the life cycle of related activities" (Organisation for Economic Co-operation and Development-OECD 2011, p. 29), there are several types of eco-innovations (i.e., eco-product, eco-process and eco-organizational innovations) each of them with its own characteristics and contribution to firm performance (Cheng et al. 2014). In particular, eco-product innovations refer to the improvement of existing products or the introduction of new ones with the aim of reducing their environmental impacts throughout their whole life cycle (Peng and Liu 2016) through a change in the product's 
characteristics (e.g., substituting inputs for renewable ones, redesigning products and packaging, improving water usage or electricity consumption associated with its use, etc.) Although a standardized definition of ecological products does not exist (Moisander 2007; Durif et al. 2010; Sdrolia and Zarotiadis 2019) being used interchangeably terms such as green products, sustainable products, and environmentally friendly products (Saluja 2016), overall, arguments converge around the reduction of the environmental burden caused by a product during its whole life cycle. This reduction should be considered from a holistic perspective (Sdrolia and Zarotiadis 2019) including all possible environmental impacts generated before, during, and after the use of the product (Dangelico and Pontrandolfo 2010).

In this sense, the reduction of environmental impacts derived from eco-product innovations may stem both from their use (e.g., reduced water usage, fuel and energy consumption, $\mathrm{CO}_{2}$ emissions) and/or their design and production (i.e., products that require less input of resources or are made of recycled and/or recyclable materials, use less toxic substances and scarce natural resources, are more easily recyclable, have not been tested on animals, and are produced by using more efficient and cleaner technologies).

Furthermore, in some cases, the functionalities and environmental advantages of environmentally friendly products are difficult to observe by potential buyers (Van Loo et al. 2015), are very novel (Shim et al. 2018) or their use may imply changes in consumption or use patterns (e.g., electric cars, reusable diapers) affecting customers' purchasing behavior. In this respect, the more observable the advantages and characteristics of environmentally friendly products are, the greater the adoption of this type of environmental innovations (Jansson 2011).

Therefore, it could be said that customers' interest in environmentally friendly products depends on the type (characteristics) of such eco-product innovations. In this sense, proximity to final customers determines the strength of consumer pressure to eco-innovate (Doran and Ryan 2012; Hojnik and Ruzzier 2016) as well as the impact of eco-product innovations on the firm's image (Demirel and Kesidou 2019). In turn, as Cruzel et al. (2014, p. 1506) noted, customer pressures also affect the type of environmental innovation approach that a company develops.

Accordingly, it seems interesting to determine consumers' preferences in relation to eco-product innovations. Specifically, we consider two alternatives: eco-design and products with ecological use. The former refers to "the integration of environmental aspects into product design and development with the aim of reducing adverse environmental impacts throughout a product's life cycle" (ISO 2020). Thus, environmental innovation approaches related to eco-design combine creativity, innovation and environmental responsibility to satisfy the demands of environmentally conscious customers (Plouffe et al. 2011) who consider that environmental criteria are as important as the quality, price, and technical feasibility (Cruzel et al. 2014).

On the other hand, environmental innovations related to products with ecological use are focused on the reduction of the environmental impacts associated with the use of a product (e.g., reduced water usage, energy and fuel consumption, greenhouse gases and pollutants emissions, elimination of heavy metals in batteries, etc.). In some cases, these products with ecological use may imply a change in the customers' consumption and use patterns (e.g., electric cards or reusable diapers).

In many cases, the purchase of eco-designed products only implies to consumers paying a price premium (Mintel 2009) that environmentally aware consumers are often willing to pay (Ward et al. 2011), whereas products with ecological use may also imply a change in consumption and use patterns and, consequently, it could be argued that the purchase of such products is associated with a higher level of environmental commitment by consumers. However, to the authors' knowledge, there is no theory or empirical evidence regarding customer preferences or buying criteria in this regard.

Therefore, in order to determine whether consumers have a preference for one of these alternatives and, in this case, what alternative is preferred by consumers, the following hypotheses are stated. 
Hypothesis 2a (H2a). Consumers show a greater preference for environmental innovations in eco-design over products with ecological use.

Hypothesis $\mathbf{2 b} \mathbf{b} \mathbf{H} \mathbf{2 b})$. Consumers show a greater preference for environmental innovations in products with ecological use over eco-design.

\section{Methodology}

\subsection{Sample}

The sample consists of 5391 international companies belonging to different activity sectors whose economic, financial, social, and environmental information is available in the Thomson Reuters database. The period of study encompasses sixteen years (2002-2017).

To determine the sample and the period of study we started by selecting those listed firms worldwide with information relating to the environmental innovation variables contained in the empirical models to be estimated (i.e., ecological products, ecological design, and ecological use) available in the Thomson Reuters database. Afterwards, we eliminated those firms that did not have information for the remaining variables included in the models. Lastly, in order to control endogeneity problems, we eliminated those firms with a frequency of fewer than eight years.

Thus, the sample corresponds to an unbalanced data panel of 51,666 observations. The firms included in the sample operate in 71 countries and 10 activity sectors.

\subsection{Models, Variables and Analysis Techniques}

The overall objective of this paper is to analyze the impact of eco-product innovations on sales growth. To test the two research hypotheses associated with this objective, we propose the models represented in Equations (1) and (2), respectively.

Sales_Growth $\mathrm{i}_{\mathrm{i}, \mathrm{t}}$

$$
\begin{aligned}
& =\omega_{0}+\omega_{1} \text { Ecological_Product }_{i, \mathrm{t}}+\omega_{2} \text { Firm_Size }_{\mathrm{i}, \mathrm{t}}+\omega_{3} \text { Leverage }_{i, \mathrm{t}} \\
& +\omega_{4} \text { Cash }_{\mathrm{i}, \mathrm{t}}+\omega_{5} \text { Work_Cap }_{\mathrm{i}, \mathrm{t}}+\omega_{6} \operatorname{Div}_{\mathrm{i}, \mathrm{t}}+\omega_{7} \operatorname{Inter}_{-} \text {Sales }+\omega_{8} \text { Capex }_{\mathrm{i}, \mathrm{t}} \\
& +\omega_{9} \mathrm{R}_{\mathrm{i}} \mathrm{D}_{\mathrm{i}, \mathrm{t}}+\omega_{10} \text { Firm_Age }_{\mathrm{i}, \mathrm{t}}+\omega_{11} \text { CopGov_Prac }_{\mathrm{i}, \mathrm{t}}+\omega_{12} \text { Social_Perf }_{\mathrm{i}, \mathrm{t}} \\
& +\omega_{13} \text { Ncsrpi }_{\mathrm{i}, \mathrm{t}}+\omega_{14} \mathrm{Icsrpi}_{\mathrm{i}, \mathrm{t}}+\omega_{15} \text { Industry }_{\mathrm{i}, \mathrm{t}}+\omega_{16} \text { Country }_{\mathrm{i}}+\omega_{17} \text { Year }_{\mathrm{t}} \\
& +\varepsilon_{\mathrm{it}}+\eta_{\mathrm{i}}
\end{aligned}
$$

Sales_Growth $\mathrm{i}_{\mathrm{i}, \mathrm{t}}$

$$
\begin{aligned}
& =\omega_{0}+\omega_{1} \text { Ecological_Design }_{\mathbf{i}, \mathbf{t}}+\omega_{2} \text { Ecological_Use }_{\mathbf{i}, \mathbf{t}}+\omega_{3} \text { Firm }_{\text {Sizei }, \mathrm{t}} \\
& +\omega_{4} \text { Leverage }_{\mathrm{i}, \mathrm{t}}+\boldsymbol{\omega}_{5} \text { Cash }_{\mathrm{i}, \mathrm{t}}+\omega_{6} \text { Work }_{\text {Capi,t }}+\omega_{7} \text { Div }_{\mathrm{i}, \mathrm{t}}+\omega_{8} \text { Inter }_{\text {Sales }} \\
& +\omega_{9} \text { Capex }_{i, t}+\omega_{10} R \& D_{i, t}+\omega_{11} \text { Firm_Age } e_{i, t}+\omega_{12} \text { CopGov_Prac }{ }_{i, t} \\
& +\omega_{13} \text { Social_Perf }_{\mathrm{i}, \mathrm{t}}+\omega_{14} \mathrm{Ncsrpi}_{\mathrm{i}, \mathrm{t}}+\omega_{15} \text { Icsrpi }_{\mathrm{i}, \mathrm{t}}+\boldsymbol{\omega}_{16} \text { Industry }_{\mathrm{i}, \mathrm{t}} \\
& +\omega_{17} \text { Country }_{\mathrm{i}}+\omega_{18} \text { Year }_{\mathrm{t}}+\varepsilon_{\mathrm{it}}+\eta_{\mathrm{i}}
\end{aligned}
$$

In both equations, the dependent variable (Sales_Growth) corresponds to the year-onyear increase in the company's sales figures. In this sense, a higher sales increase means that consumers value the company's products favorably.

In Equation (1), the independent variable (Ecological_Product) corresponds to an ordinal variable that takes values between 0 and 2 , identifying whether companies design and manufacture products in an ecological way and/or the use of these products is respectful with the environment. Taking into account the "holistic nature" of ecological products (Sdrolia and Zarotiadis 2019), our variable reflects the phases of a product's life cycle in which a reduction of its environmental burden occurs. Thus, in the case that the reduction of environmental impacts derived from a company's eco-product innovations stems only from their use (i.e., ecological use) or their design (i.e., eco-design) the variable would take the value 1, whereas when the reduction of environmental impacts derived from a company's eco-product innovations stems both from their use and their design the variable would take the value 2 . The value 0 corresponds to those companies that have not developed any kind of eco-product innovations. 
This variable is broken down into two variables in Equation (2), Ecological_Design and Ecological_Use, which identify the investment in eco-design projects and the commercialization of products of ecological, respectively. Thus, Ecological_Design is a dummy variable that takes the value 1 if the company carries out eco-design projects and 0 otherwise, whereas Ecological_Use is a dummy variable that takes the value 1 if the company produce and commercialize products of ecological use and 0 otherwise.

To avoid biased results, both equations include several control variables, which have been selected based on the previous literature (i.e., García-Sánchez et al. 2020a, 2020b). Such variables are related to firm's characteristics (e.g., size, leverage, and age), factors associated with the development of environmental capabilities (e.g., investment in physical capital and $R \& D$, international sales, sustainable performance), corporate governance mechanisms, and institutional pressures at country and sector level. Their description can be seen in detail in Table 1.

Table 1. Control variables definition.

\begin{tabular}{|c|c|c|}
\hline Variable & Definition & Studies \\
\hline Firm_Size & Logarithm of total assets & $\begin{array}{l}\text { Przychodzen and Przychodzen (2015); Acosta-Prado et al. (2017); } \\
\text { Zhang et al. (2019); García-Sánchez et al. (2020a, 2020b); Oh et al. } \\
\text { (2020) }\end{array}$ \\
\hline Leverage & $\begin{array}{l}\text { Financial leverage through the proportion of foreign } \\
\text { funds and equity }\end{array}$ & $\begin{array}{l}\text { Lee and Min (2015); Przychodzen and Przychodzen (2015); } \\
\text { García-Sánchez and Martínez-Ferrero (2019); Zhang et al. (2019); } \\
\text { García-Sánchez et al. (2020a, 2020b); Oh et al. (2020) }\end{array}$ \\
\hline Cash & Liquid money and other means of immediate disposal & \\
\hline Work_Cap & The fund maneuver or liquidity of the company & García-Sánchez et al. (2020a, 2020b) \\
\hline Dividend & Dividends accrued per share & $\begin{array}{l}\text { García-Sánchez and Martínez-Ferrero (2019); García-Sánchez et al. } \\
\text { (2020a, 2020b) }\end{array}$ \\
\hline Inter_Sales & Percentage of sales in markets other than domestic & García-Sánchez et al. (2020a, 2020b) \\
\hline Capex & Investment in physical capital relativized by sales & Lee and Min (2015); García-Sánchez et al. (2020a, 2020b) \\
\hline $\mathrm{R} \& \mathrm{D}$ & Investment in $\mathrm{R}+\mathrm{D}+\mathrm{i}$ relativized by sales & $\begin{array}{l}\text { Demirel and Kesidou (2019); García-Sánchez and Martínez-Ferrero } \\
\text { (2019); García-Sánchez et al. (2020a, 2020b) }\end{array}$ \\
\hline Firm_Age & The age of the company & Acosta-Prado et al. (2017); García-Sánchez et al. (2020a, 2020b) \\
\hline CopGov_Prac & $\begin{array}{l}\text { Score that reflects the good corporate governance } \\
\text { practices of the company }\end{array}$ & García-Sánchez et al. (2020a) \\
\hline Social_Perf & Score that reflects the social performance of the company & García-Sánchez et al. (2020a) \\
\hline NCSRPI & $\begin{array}{l}\text { Level of orientation towards the stakeholders of the } \\
\text { country of origin of the company. }\end{array}$ & Amor-Esteban et al. (2019a); García-Sánchez et al. (2020a, 2020b) \\
\hline ICSRPI & $\begin{array}{l}\text { Aggregate indicator of institutional pressures at the } \\
\text { sectoral level. }\end{array}$ & Amor-Esteban et al. (2018, 2019b). García-Sánchez et al. (2020b) \\
\hline
\end{tabular}

The equations will be estimated using the dynamic estimator in two stages, based on the generalized method of moments (GMM) proposed by Arellano and Bond (1991) available from Stata through Roodman (2009). The models incorporate the error term that is disaggregated into $\eta$ and $\varepsilon$, with the objective of controlling for unobservable heterogeneity and incorporating random disturbance, respectively. Additionally, three ordinal variables were included to control the effect of Country, Industry, and Year (García-Sánchez et al. 2020b).

\section{Results and Discussion}

\subsection{Descriptive Statistics}

Table 2 shows the descriptive statistics (i.e., mean and standard deviation) for the dependent, independent, and control variables considered in the analysis. It can be seen that the year-on-year sales growth stands at $3.20 \%$, with a variability of $+0.60 \%$. On average, $39 \%$ of companies have developed some kind of eco-product innovation. Specifically, $11 \%$ of companies have invested in eco-design, whereas $47 \%$ produce and commercialize products with ecological use. 
Table 2. Descriptive statistics.

\begin{tabular}{ccc}
\hline Variable & Mean & Std. Dev. \\
\hline Sales_Growth & 0.03 & 0.60 \\
Firm_Size & 15.74 & 3.02 \\
Leverage & 0.82 & 0.78 \\
Cash & 4.27 & 86.16 \\
Work_Cap & 4.56 & 1.54 \\
Dividend & 45.77 & 612.36 \\
Inter_Sales & 0.31 & 0.68 \\
Capex & 112.07 & 5104.84 \\
R\&D & 159.34 & 6944.85 \\
Firm_Age & 33.11 & 30.69 \\
CopGov_Prac & 51.34 & 30.91 \\
Social_Perf & 14.3 & 18.54 \\
NCSRPI & -1.82 & 8.95 \\
ICSRPI & 0.04 & 3.02 \\
\hline Ecological_Products & Frequency & \\
Ecological_Design & 0.39 & \\
Ecological_Use & 0.11 & \\
\hline
\end{tabular}

Table 3 shows the results obtained in the analysis of correlations between the different variables considered in the empirical models proposed to test the research hypotheses. As can be seen, the coefficients are not high, which suggests the non-existence of multicollinearity problems.

Table 3. Bivariate correlations $\left.{ }^{* * *} p<0.01,{ }^{* *} p<0.05,{ }^{*} p<0.1\right)$.

\begin{tabular}{|c|c|c|c|c|c|c|c|c|c|c|}
\hline & & 1 & 2 & 3 & 4 & 5 & 6 & 7 & 8 & 9 \\
\hline 1 & Sales_Grow & 1 & & & & & & & & \\
\hline 2 & Eco_Inn & 0.00 & 1 & & & & & & & \\
\hline 3 & Eco_Use & 0.00 & $0.71 * * *$ & 1 & & & & & & \\
\hline 4 & Eco_Des & 0.00 & $0.81^{* * *}$ & $0.49^{* * *}$ & 1 & & & & & \\
\hline 5 & Firm_Size & $0.01 * *$ & $0.24^{* * *}$ & $0.32^{* * *}$ & $0.15^{* * *}$ & 1 & & & & \\
\hline 6 & Leverage & 0.00 & 0.00 & 0.00 & 0.00 & 0.00 & 1 & & & \\
\hline 7 & Cash & 0.00 & 0.00 & $0.02^{* * *}$ & 0.01 & $0.03^{* * *}$ & 0.00 & 1 & & \\
\hline 8 & Wor_Cap & 0.00 & $0.04^{* * *}$ & $0.04^{* * *}$ & $0.04^{* * *}$ & $0.08^{* * *}$ & 0.00 & 0.00 & 1 & \\
\hline 9 & Dividend & 0.00 & $0.01^{* * *}$ & 0.00 & $0.01^{* *}$ & $0.14^{* * *}$ & 0.00 & 0.00 & $0.12 * *$ & 1 \\
\hline 10 & Inter_Sales & 0.00 & $0.07^{* * *}$ & $0.09 * * *$ & $0.07^{* * *}$ & $0.02 * * *$ & 0.00 & $0.01^{* * *}$ & 0.00 & $-0.01^{* *}$ \\
\hline 11 & Capex & 0.00 & $-0.01^{* * *}$ & $-0.01^{* * *}$ & -0.01 & $-0.02^{* * *}$ & -0.01 & $-0.03^{* * *}$ & 0.00 & 0.00 \\
\hline 12 & $\mathrm{R} \& \mathrm{D}$ & 0.00 & $-0.01 *$ & -0.01 & -0.01 & $-0.02^{* * *}$ & -0.01 & $-0.05^{* * *}$ & 0.00 & 0.00 \\
\hline 13 & Firm_Age & 0.00 & $0.19 * * *$ & $0.26^{* * *}$ & $0.15^{* * *}$ & $0.22^{* * *}$ & 0.00 & $0.01^{* * *}$ & $0.01^{* * *}$ & $-0.01 *$ \\
\hline 14 & CopGov_Prac & $-0.01^{* *}$ & $-0.04^{* * *}$ & $-0.05^{* * *}$ & $-0.04^{* * *}$ & $-0.21^{* * *}$ & 0.00 & 0.00 & $-0.04^{* * *}$ & $-0.07^{* * *}$ \\
\hline 15 & Social_Perf & 0.01 & -0.01 & $-0.03^{* * *}$ & $-0.01 *$ & $-0.02^{* * *}$ & -0.01 & 0.00 & 0.01 & 0.00 \\
\hline 16 & NCSRPI & 0.00 & $0.04^{* * *}$ & $0.12^{* * *}$ & $0.03^{* * *}$ & $-0.01^{* * *}$ & $0.01 *$ & $0.01 * *$ & $-0.02^{* * *}$ & $0.02^{* * *}$ \\
\hline \multirow[t]{2}{*}{17} & ICSRPI & 0.00 & $0.16^{* * *}$ & $0.17^{* * *}$ & $0.13^{* * *}$ & $-0.07^{* * *}$ & 0.00 & 0.00 & $0.02 * * *$ & $-0.01^{* * *}$ \\
\hline & & 10 & 11 & 12 & 13 & 14 & 15 & 16 & 17 & \\
\hline 10 & Inter_Sales & 1 & & & & & & & & \\
\hline 11 & Capex & 0.00 & 1 & & & & & & & \\
\hline 12 & R\&D & $-0.03 * * *$ & $0.02 * * *$ & 1 & & & & & & \\
\hline 13 & Firm_Age & $0.08^{* * *}$ & $-0.01^{* * *}$ & $-0.02 * *$ & 1 & & & & & \\
\hline 14 & CopGov_Prac & -0.01 & 0.00 & 0.01 & $-0.01^{* *}$ & 1 & & & & \\
\hline 15 & Social_Perf & $0.01 * *$ & $0.02 * * *$ & -0.01 & $-0.05^{* * *}$ & 0.01 & 1 & & & \\
\hline 16 & NCSRPI & $0.15^{* * *}$ & $0.02 * * *$ & $-0.01^{* *}$ & $0.09^{* * *}$ & $-0.07^{* * *}$ & $0.01 *$ & 1 & & \\
\hline 17 & ICSRPI & $0.13^{* * *}$ & $0.02^{* * *}$ & $-0.01 *$ & $0.08^{* * *}$ & $-0.01^{* * *}$ & 0.00 & $0.04^{* * *}$ & 1 & \\
\hline
\end{tabular}




\subsection{Dependence Models Results}

Table 4 shows the results obtained for the estimation of the models proposed to test our research hypotheses. In this regard, it can be observed that in Equation (1), the variable Ecological_Products positively and significantly impacts (coeff. $=29.73$ ) on the year-on-year sales growth for a confidence level of $99 \%$, allowing us to confirm the hypothesis $\mathrm{H} 1$ that there is a positive association between eco-product innovation and sales growth.

Table 4. Results of explanatory models $\left({ }^{* * *} p<0.01\right)$.

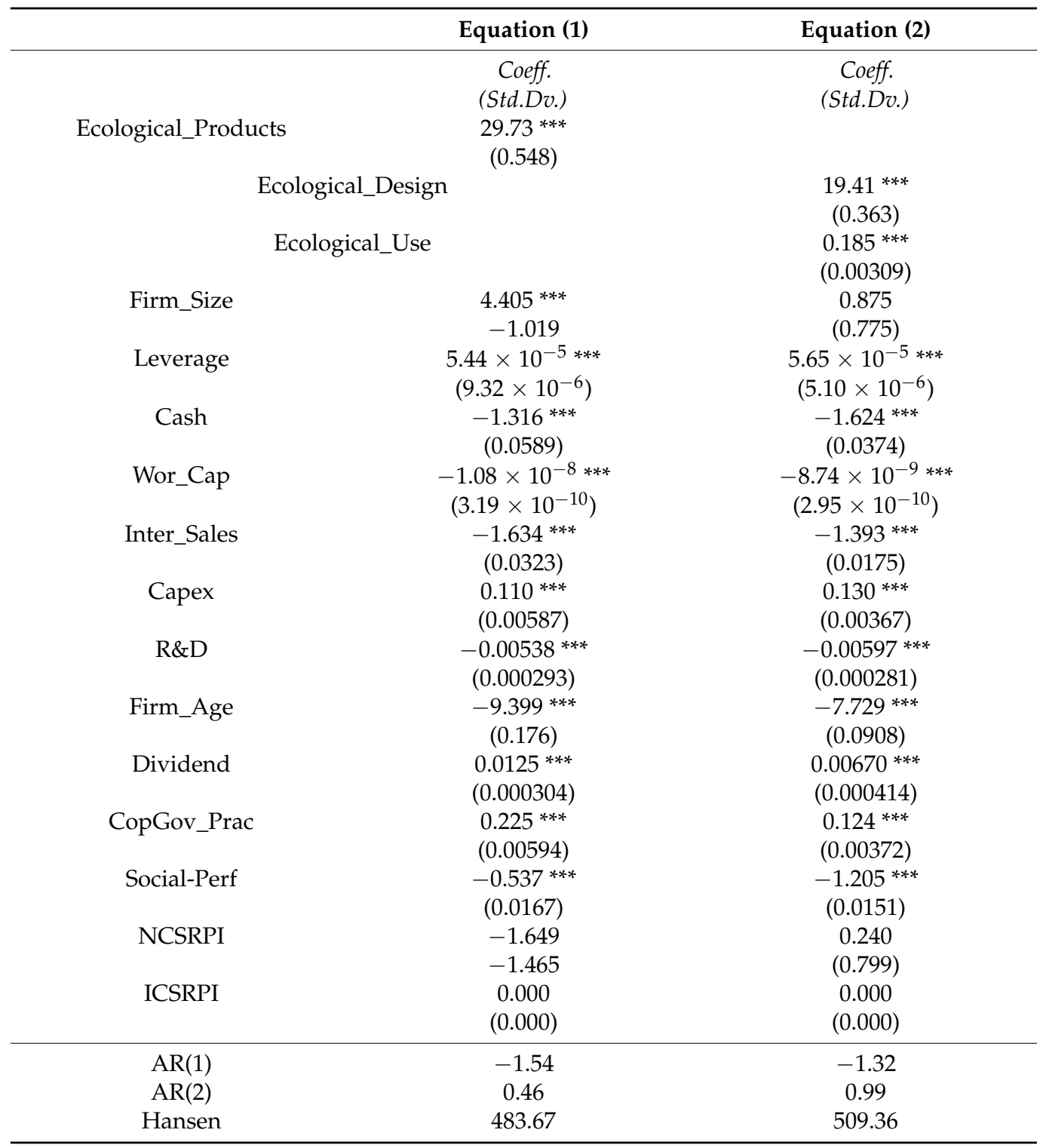

The results obtained by estimating Equation (2) also allow us to confirm the hypothesis $\mathrm{H} 2 \mathrm{a}$, which posited that consumers show a greater preference for environmental innovations in eco-design over products with ecological use. In this sense, even though both variables, Ecological_Design (coeff. $=19.41$ ) and Ecological_Use (coeff. $=0.185)$, have a significant impact on year-on-year sales growth for a $99 \%$ confidence level, the impact of the Ecological_Design variable is higher.

\subsection{Discussion}

Market sensing capabilities (i.e., a firm's capability to understand market signals and trends) are critical for business success (Demirel and Kesidou 2019). In this sense, given 
that consumers are increasingly sensitized to environmental and ethical considerations (Sehgal and Singh 2010; Hojnik and Ruzzier 2016), customer demand for environmentally friendly products has been identified as a key driving force of eco-innovation (Doran and Ryan 2012; Guoyou et al. 2013). However, the existence of an "attitude-behavior gap" identified by prior studies (Wong et al. 1996; Shim et al. 2018) casts doubts about whether consumers' environmental attitude does translate into purchasing behavior.

Our research hypotheses concern the impact of eco-product innovations on sales growth. Results in Table 4 show a positive association between eco-product innovation and sales growth indicating an interest of consumers in environmentally friendly products is reflected in their choices, thereby positively affecting sales. Thus, it can be inferred that consumers prefer environmentally friendly products, which leads to a growth of the sales of the companies involved in eco-product innovation projects.

This result is consistent with the findings obtained by Oh et al. (2020), who in the Korean context, found that eco-labeling resulted in sales growth, Cheng et al. (2014), who document a positive impact of eco-product innovations on Taiwanese firms' sales, and Alos-Simo et al. (2020), who observed that eco-innovation positively influences sales volume of both new firm products and new market products. Furthermore, this finding is also in line with other studies that showed a positive and significant relationship between environmental innovation and sales growth (e.g., Horbach (2008) in the German context, D. Zhang et al. (2019) for Chinese manufacturing companies, and Colombelli et al. (2019) in the case of manufacturing companies operating in six European countries: France, Germany, Italy, Spain, Sweden, and the UK).

Additionally, while Oh et al. (2020) observed that the effect of eco-labeling on sales growth was valid only for the two years following the certification and sales growth decreased from the third year, our findings indicate that the positive impact of eco-product innovations on sales extends over time, which enables us to confirm the potential of this type of environmental innovations to generate sustainable competitive advantages and economic benefits.

We further analyzed consumers' preferences for environmentally friendly products by considering the effect on sales growth of two different alternatives of eco-product innovation: eco-design and products of ecological use. As it is shown in Table 4, although both alternatives are positively valued by consumers, having a positive impact on sales growth, the impact of eco-product innovations based on eco-design is higher.

Therefore, our results seem to indicate that consumers show a greater preference for environmental innovations in eco-design than for products with ecological use. This result corroborates Plouffe et al.'s contention (2011) that "eco-designed products provide greater satisfaction to consumers" (p. 574) and confirm their results regarding eco-design can provide companies economic benefits through an increase in their sales.

\section{Concluding Remarks}

Environmental innovation and related relevant issues (i.e., its determinants and outcomes) have attracted growing attention by researchers and practitioners (Cancino et al. 2018; Pacheco et al. 2018). Prior studies have identified customer pressure as a main driving force of eco-innovation (Doran and Ryan 2012; Guoyou et al. 2013; Hojnik and Ruzzier 2016). In this sense, it has been argued that the consumers' growing demand for environmentally friendly products forces companies to choose between involving themselves in eco-innovation projects aimed at reducing the negative environmental impacts of their products or losing their clients (Hojnik and Ruzzier 2016). However, some authors have noticed the existence of an "attitude-behavior gap" that implies that consumers' stated environmental concern does not always translate into actual purchase behavior (Wong et al. 1996; Shim et al. 2018).

Given that consumers are a major stakeholder group whose demands and preferences have a strong influence on corporate strategies, this paper aimed to analyze if the companies that invest in eco-product innovation are valued by consumers, showing a higher sales growth. 
Specifically, we propose that eco-product innovation has a positive effect on a firm's sales growth. Additionally, we aim to analyze the consumers' preferences in relation to eco-product innovations considering two alternative approaches that companies can follow in this respect: eco-design and products with ecological use. The results obtained for an unbalanced sample of 5391 international companies corresponding to the period 2002-2017 (51,666 observations) show that these proactive environmental innovation strategies are positively valued by consumers, having a positive impact on the companies' sales growth. Furthermore, the findings indicate that consumers show a greater preference for environmental innovations in eco-design than for products with ecological use.

Our findings have some theoretical and practical implications. From a theoretical viewpoint, our findings demonstrate that environmentally friendly products have a positive impact on the market. Accordingly, they confirm the arguments that consumer preference for environmentally friendly products helps to explain the economic impact of eco-innovation through its positive effect on sales. The environmental attributes of products attract consumers' attention so that companies can use such attributes as a differentiating tool in order to obtain sustainable competitive advantages and economic benefits. Thus, eco-product innovation enables companies to fit their offer to the environmentally conscious consumers' growing demand positively affecting their sales volume. These findings are in line with prior research's results regarding a positive and significant relationship between eco-product innovations and sales (Cheng et al. 2014; Colombelli et al. 2019; Zhang et al. 2019; Alos-Simo et al. 2020; Oh et al. 2020). Furthermore, the results also confirm prior findings regarding the key role that customer demands play in driving firms to develop environmental innovation (Doran and Ryan 2012; Guoyou et al. 2013; Hojnik and Ruzzier 2016).

Additionally, our study provides novel empirical evidence about the preferences of consumers in relation to two different approaches of eco-product innovation (i.e., ecodesign and eco-use), indicating which is most valued by them. Hence, our findings indicate that, even though environmental innovations in both eco-design and products with ecological use have a positive impact on sales growth, the impact of eco-design is higher, so that it can be inferred that consumers show a greater preference for this approach of eco-product innovation.

With regard to the study's practical implications, our results have several managerial and policy implications. From a managerial point of view, our findings provide an orientation to managers in order to design strategies aimed at promoting environmental innovation and competitiveness. On the one hand, given that sustainable product innovation requires to invest greater financial resources in the short-term while their returns are uncertain, by demonstrating that this type of environmental innovations has a positive effect on sales growth, our findings provide some support to managers when considering this kind of strategies and allow them to understand how eco-product innovation can help firms to improve performance. On the other hand, our findings provide an indication of which eco-product innovation approaches (i.e., eco-design or eco-use) are most valued by customers, which could guide companies when selecting environmental product innovation projects.

Furthermore, demonstrating that eco-product innovations have a positive effect on firms' growth, our findings allow other key important stakeholders, such as shareholders and institutional investors, to support investments in this type of environmental project with certainty that they will contribute to enhancing firm value. From a broader perspective, this study allows identifying a channel (i.e., eco-product innovation) through which a firm can contribute to the dynamics of social and economic growth. As regards the study's public policy implications, given that, as noted by Jansson (2011), the development of environmentally friendly products by companies will not have the desired positive environmental effects unless consumers actually purchase them and adopt the greener lifestyles associated with their use, by showing that consumers actually value and purchase this environmentally friendly products, our results could provide an orientation to policy- 
makers when designing regulations and policies to promote investments in environmental innovation in products by companies.

Finally, it should be noticed that this study is subject to some limitations. Although we have interpreted sales growth as resulting from consumer preference for environmentally friendly products, as Oh et al. (2020) noted, this may not be the only cause. In this sense, future studies could develop additional analyses to deepen the understanding of the exact cause of sales growth. Furthermore, given that differences among sectors may affect consumers' demands and price sensitivity (Hojnik et al. 2018) as well as the firms' propensity to eco-innovate (Cai and Zhou 2014; Alos-Simo et al. 2020), future studies could consider analyzing the effect of the activity sector in which a company operates on the relationship between eco-product innovation and sales growth.

Author Contributions: The whole article is the result of a joint project and shared effort: Conceptualization, C.A.-G. and F.M.S.-R.; methodology, C.A.-G. and F.M.S.-R.; validation, C.A.-G. and F.M.S.-R.; formal anal-ysis, C.A.-G. and F.M.S.-R.; investigation, C.A.-G. and F.M.S.-R.; resources, C.A.-G. and F.M.S.-R.; data curation, C.A.-G. and F.M.S.-R.; writing-original draft preparation, C.A.-G. and F.M.S.-R.; writing—review and editing, C.A.-G. and F.M.S.-R.; visualization, C.A.-G. and F.M.S.-R.; supervision, C.A.-G. and F.M.S.-R.; project administration, C.A.-G. and F.M.S.-R. Both authors have read and agreed to the published version of the manuscript.

Funding: This research received no external funding.

Institutional Review Board Statement: Not applicable.

Informed Consent Statement: Not applicable.

Data Availability Statement: The data presented in this study are available on request from the corresponding author.

Conflicts of Interest: The authors declare no conflict of interest.

\section{References}

Acosta-Prado, Julio César, Mónica Longo-Somoza, and María Belén Lozano. 2017. Does family ownership affect innovation activity? A focus on the biotechnological industry. Innovar: Revista de Ciencias Administrativas y Sociales 27: 11-23. [CrossRef]

Albino, Vito, Azzurra Balice, and Rosa Maria Dangelico. 2009. Environmental strategies and green product development: An overview on sustainability-driven companies. Business Strategy and the Environment 18: 83-96. [CrossRef]

Alos-Simo, Lirios, Antonio J. Verdu-Jover, and José M. Gomez-Gras. 2020. Does activity sector matter for the relationship between eco-innovation and performance? Implications for cleaner production. Journal of Cleaner Production 263: 121544. [CrossRef]

Al-Shammari, Marwan, Abdul Rasheed, and Hussam A. Al-Shammari. 2019. CEO narcissism and corporate social responsibility: Does CEO narcissism affect CSR focus? Journal of Business Research 104: 106-17. [CrossRef]

Amor-Esteban, Víctor, Mª-Purificación Galindo-Villardón, and Isabel-María García-Sánchez. 2018. Useful information for stakeholder engagement: A multivariate proposal of an Industrial Corporate Social Responsibility Practices Index. Sustainable Development 26 : 620-37. [CrossRef]

Amor-Esteban, Víctor, Ma-Purificación Galindo-Villardón, and Isabel-María García-Sánchez. 2019a. An extension of the industrial corporate social responsibility practices index: New information for stakeholder engagement under a multivariate approach. Corporate Social Responsibility and Environmental Management 26: 127-40. [CrossRef]

Amor-Esteban, Víctor, Ma-Purificación Galindo-Villardón, and Isabel-María García-Sánchez. 2019b. A Multivariate Proposal for a National Corporate Social Responsibility Practices Index (NCSRPI) for International Settings. Social Indicators Research 143: 525-60. [CrossRef]

Arellano, Manuel, and Sephen Bond. 1991. Some tests of specification for panel data: Monte Carlo evidence and an application to employment equations. The Review of Economic Studies 58: 277-97. [CrossRef]

Arena, Claudia, Giovanna Michelon, and Grzegorz Trojanowski. 2018. Big egos can be green: A study of CEO hubris and environmental innovation. British Journal of Management 29: 316-36. [CrossRef]

Bennett, Martin, and Peter James. 1998. Environment under the Spotlight: Current Practice and Future Trends in Environment-Related Performance Measurement for Business. London: The Association of Chartered Certified Accountants, Available online: http: //hdl.handle.net/10068/394084 (accessed on 9 December 2020).

Blake, James. 1999. Overcoming the 'value-action gap'in environmental policy:Tensions between national policy and local experience. Local Environment 4: 257-78. [CrossRef] 
Brosdahl, Deborah J., and Jason M. Carpenter. 2010. Consumer knowledge of the environmental impacts of textile and apparel production, concern for the environment, and environmentally friendly consumption behavior. Journal of Textile and Apparel, Technology and Management 6: 1-9.

Cai, Wu-Gan, and Xiao-Liang Zhou. 2014. On the drivers of eco-innovation: Empirical evidence from China. Journal of Cleaner Production 79: 239-48. [CrossRef]

Cancino, Christian A., Ariel I. La Paz, Arkalgud Ramaprasad, and Thant Syn. 2018. Technological innovation for sustainable growth: An ontological perspective. Journal of Cleaner Production 179: 31-41. [CrossRef]

Carfora, Alfonso, Giuseppe Scandurra, and Antonio Thomas. 2021. Determinants of environmental innovations supporting small-and medium-sized enterprises sustainable development. Business Strategy and the Environment. [CrossRef]

Carrete, Lorena, Raquel Castaño, Reto Felix, Edgar Centeno, and Eva González. 2012. Green consumer behavior in an emerging economy: Confusion, credibility, and compatibility. Journal of Consumer Marketing 29: 470-81. [CrossRef]

Chen, Yu-Shan, and Ching-Hsun Chang. 2012. Greenwash and green trust: The mediation effects of green consumer confusion and green perceived risk. Journal of Business Ethics 114: 489-500. [CrossRef]

Cheng, Colin C., and Eric C. Shiu. 2012. Validation of a proposed instrument for measuring eco-innovation: An implementation perspective. Technovation 32: 329-44. [CrossRef]

Cheng, Colin C., Chen-Lung Yang, and Chwen Sheu. 2014. The link between eco-innovation and business performance: A Taiwanese industry context. Journal of Cleaner Production 64: 81-90. [CrossRef]

Chiou, Tzu-Yun, Hing Kai Chan, Fiona Lettice, and Sai Ho Chung. 2011. The influence of greening the suppliers and green innovation on environmental performance and competitive advantage in Taiwan. Transportation Research Part E: Logistics and Transportation Review 47: 822-36. [CrossRef]

Colombelli, Alessandra, Jackie Krafft, and Francesco Quatraro. 2019. Firms' growth, green gazelles and eco-innovation: Evidence from a sample of European firms. Small Business Economics, 1-18. [CrossRef]

Cruzel, François, Flore Vallet, Benjamin Tyl, G. Bertoluci, and Yann Leroy. 2014. Eco-design vs. eco-innovation: An industrial survey. Paper presented at the DS 77: DESIGN 2014 13th International Design Conference, Dubrovnik, Croatia, May 19-22.

da Silva Monteiro, Sónia María, and Beatriz Aibar-Guzmán. 2009. Determining factors of environmental strategic positioning adopted by Portuguese large companies. Social Responsibility Journal 5: 478-98. [CrossRef]

Dangelico, Rosa María, and Pierpaolo Pontrandolfo. 2010. From green product definitions and classifications to the Green Option Matrix. Journal of Cleaner Production 18: 1608-28. [CrossRef]

Del Río Pablo, Javier Carrillo-Hermosilla, and Totti Könnölä. 2010. Policy strategies to promote eco-innovation: An integrated framework. Journal of Industrial Ecology 14: 541-57. [CrossRef]

del Val Segarra Oña, María, Angel Peiró Signes, and José Mondejar Jimenez. 2013. Identifying variables affecting the proactive environmental orientation of firms: An empirical study. Polish Journal of Environmental Studies 22: 873-80. Available online: https: / / riunet.upv.es/handle/10251/60004 (accessed on 12 December 2020).

Demirel, Pablo, and Effie Kesidou. 2019. Sustainability-oriented capabilities for eco-innovation: Meeting the regulatory, technology, and market demands. Business Strategy and the Environment 28: 847-57. [CrossRef]

Doran, Justin, and Geraldine Ryan. 2012. Regulation and firm perception, eco-innovation and firm performance. European Journal of Innovation Management 15: 421-41. [CrossRef]

Durif, Fabien, Caroline Boivin, and Charles Julien. 2010. In search of a green product definition. Innovative Marketing 6: 25-33.

Gallego-Álvarez, Isabel, José Manuel Prado-Lorenzo, and Isabel-María García-Sánchez. 2011. Corporate social responsibility and innovation: A resource-based theory. Management Decision 49: 1709-27. [CrossRef]

García-Sánchez, Isabel-María, and Jennifer Martínez-Ferrero. 2019. Chief executive officer ability, corporate social responsibility, and financial performance: The moderating role of the environment. Business Strategy and the Environment 28: 542-55. [CrossRef]

García-Sánchez, Isabel María, Isabel Gallego-Álvarez, and José-Luis Zafra-Gómez. 2020a. Do the ecoinnovation and ecodesign strategies generate value added in munificent environments? Business Strategy and the Environment 29: 1021-33. [CrossRef]

García-Sánchez, Isabel-María, Cristina Aibar-Guzmán, and Beatriz Aibar-Guzmán. 2020b. The effect of institutional ownership and ownership dispersion on eco-innovation. Technological Forecasting and Social Change 158: 120173. [CrossRef]

Gleim, Mark R., Jeffery S. Smith, Demetra Andrews, and J. Joseph Cronin Jr. 2013. Against the Green: A Multi-method Examination of the Barriers to Green Consumption. Journal of Retailing 89: 44-61. [CrossRef]

Guoyou, Qi, Zeng Saixing, Tam Chiming, Yin Haitao, and Zou Hailiang. 2013. Stakeholders' influences on corporate green innovation strategy: A case study of manufacturing firms in China. Corporate Social Responsibility and Environmental Management 20: 1-14. [CrossRef]

Haws, Kelly L., Karen Page Winterich, and Rebecca Walker Naylor. 2014. Seeing the world through GREEN-tinted glasses: Green consumption values and responses to environmentally friendly products. Journal of Consumer Psychology 24: 336-54. [CrossRef]

Hojnik, Jana, and Mitja Ruzzier. 2016. What drives eco-innovation? A review of an emerging literature. Environmental Innovation and Societal Transitions 19: 31-41. [CrossRef]

Hojnik, Jana, Mitja Ruzzier, and Tatiana S. Manolova. 2018. Internationalization and economic performance: The mediating role of eco-innovation. Journal of Cleaner Production 171: 1312-23. [CrossRef]

Horbach, Jens. 2008. Determinants of environmental innovation-New evidence from German panel data sources. Research Policy 37: 163-73. [CrossRef] 
ISO. 2020. Environmental Management Systems—Guidelines for Incorporating Ecodesign. Geneva: ISO.

Jansson, Johan. 2011. Consumer eco-innovation adoption: Assessing attitudinal factors and perceived product characteristics. Business Strategy and the Environment 20: 192-210. [CrossRef]

Kassinis, George I., and Andreas C. Soteriou. 2003. Greening the service-profit chain: The impact of environmental management practices. Production and Operations Management 12: 386-403. [CrossRef]

Kesidou, Effie, and Pelin Demirel. 2012. On the drivers of eco-innovations: Empirical evidence from the UK. Research Policy 41: 862-70. [CrossRef]

Kim, Woojae, Sungmin Ko, Myoungjin Oh, Ie-Jung Choi, and Jungwoo Shin. 2019. Is an incentive policy for energy efficient products effective for air purifiers? The case of South Korea. Energies 12: 1664. [CrossRef]

Kraus, Sascha, Shafique Ur Rehman, and F. Javier S. García. 2020. Corporate social responsibility and environmental performance: The mediating role of environmental strategy and green innovation. Technological Forecasting and Social Change 160: 120262. [CrossRef]

Laroche, Michel, Jasmin Bergeron, and Guido Barbaro-Forleo. 2001. Targeting consumers who are willing to pay more for environmentally friendly products. Journal of Consumer Marketing. [CrossRef]

Lee, Ki-Hoon, and Byung Min. 2015. Green R\&D for eco-innovation and its impact on carbon emissions and firm performance. Journal of Cleaner Production 108: 534-42. [CrossRef]

Luchs, Michael, Rebecca Walker Naylor, Julie R. Irwin, and Rajagopal Raghunathan. 2010. The sustainability liability: Potential negative effects of ethicality on product preference. Journal of Marketing 74: 18-31. [CrossRef]

Menguc, Bulent, and Lucie K. Ozanne. 2005. Challenges of the "green imperative": A natural resource-based approach to the environmental orientation-business performance relationship. Journal of Business Research 58: 430-38. [CrossRef]

Mintel. 2009. Ethical Clothing- UK- 2009. London: Mintel, Available online: http:/ / oxygen.mintel.com/sinatra/oxygen/display/id=39 3875 (accessed on 5 January 2021).

Moisander, Johanna. 2007. Motivational complexity of green consumerism. International Journal of Consumer Studies 31: 404-9. [CrossRef]

Mylan, Josephine, Frank W. Geels, Sally Gee, Andrew McMeekin, and Chris Foster. 2015. Eco-innovation and retailers in milk, beef and bread chains: Enriching environmental supply chain management with insights from innovation studies. Journal of Cleaner Production 107: 20-30. [CrossRef]

O'Donovan, Gary. 2002. Environmental disclosures in the annual report. Extending the applicability and predictive power of legitimacy theory. Accounting, Auditing \& Accountability Journal 15: 344-71. [CrossRef]

Oh, Myoungjin, Jungwoo Shin, Pil-Ju Park, and Sunmee Kim. 2020. Does eco-innovation drive sales and technology investment? Focusing on eco-label in Korea. Business Strategy and the Environment 29: 3174-86. [CrossRef]

Organisation for Economic Co-operation and Development-OECD. 2011. Sustainable Manufacturing and Eco-Innovation-Framework, Practices and Measurement, Synthesis Report, Paris, France. Available online: https://www.oecd.org/innovation/inno/434236 89.pdf (accessed on 7 January 2021).

Pacheco, Diego Augusto, Carla Schwengber Caten, Carlos Fernando Jung, Helena Victorovna Guitiss Navas, and Virgílio Antonio Cruz-Machado. 2018. Eco-innovation determinants in manufacturing SMEs from emerging markets: Systematic literature review and challenges. Journal of Engineering and Technology Management 48: 44-63. [CrossRef]

Peng, Xuerong, and Yang Liu. 2016. Behind eco-innovation: Managerial environmental awareness and external resource acquisition. Journal of Cleaner Production 139: 347-60. [CrossRef]

Plouffe, Sylvain, Paul Lanoie, Corinne Berneman, and Marie-France Vernier. 2011. Economic benefits tied to ecodesign. Journal of Cleaner Production 19: 573-79. [CrossRef]

Porter, Michael, and Claas Van der Linde. 1995. Toward a new conception of the environment-competitiveness relationship. Journal of Economic Perspectives 9: 97-118. [CrossRef]

Przychodzen, Justyna, and Wojciech Przychodzen. 2015. Relationships between eco-innovation and financial performance-evidence from publicly traded companies in Poland and Hungary. Journal of Cleaner Production 90: 253-63. [CrossRef]

Reinhardt, Forest L. 1998. Environmental product differentiation: Implications for corporate strategy. California Management Review 40: 43-73. [CrossRef]

Roodman, David. 2009. How to do xtabond2: An introduction to difference and system GMM in Stata. The Stata Journal 9: 86-136. [CrossRef]

Roome, Nigel. 1992. Developing environmental management strategies. Business Strategy and the Environment 1: 11-24. [CrossRef]

Royne, Marla B., Marian Levy, and Jennifer Martinez. 2011. The public health implications of consumers' environmental concern and their willingness to pay for an eco-friendly product. Journal of Consumer Affairs 45: 329-43. [CrossRef]

Saluja, Deepali. 2016. Customer's attitude towards eco-friendly product. ANVESHAK-International Journal of Management 5. [CrossRef]

Sarkis, Joseph, Pilar González-Torre, and Belarmino Adenso-Díaz. 2010. Stakeholder pressure and the adoption of environmental practices: The mediating effect of training. Journal of Operations Management 28: 163-76. [CrossRef]

Scheidler, Sabrina, Laura M. Edinger-Schons, Jelena Spanjol, and Jan Wieseke. 2019. Scrooge Posing as Mother Teresa: How Hypocritical Social Responsibility Strategies Hurt Employees and Firms. Journal of Business Ethics 157: 339-58. [CrossRef]

Sdrolia, Evangelia, and Grigoris Zarotiadis. 2019. A comprehensive review for green product term: From definition to evaluation. Journal of Economic Surveys 33: 150-78. [CrossRef]

Sehgal, Preeti, and Neha Singh. 2010. Impact of Eco-Friendly Products on Consumer Behavior. CBS E-Journal, Biz n Bytes 6: 1-16. 
Shim, Dongnyok, Jungwoo Shin, and So-Yoon Kwak. 2018. Modelling the consumer decision-making process to identify key drivers and bottlenecks in the adoption of environmentally friendly products. Business Strategy and the Environment 27: 1409-21. [CrossRef]

Tang, Zhi, Clyde Eiríkur Hull, and Sandra Rothenberg. 2012. How Corporate Social Responsibility Engagement Strategy Moderates the CSR-Financial Performance Relationship. Journal of Management Studies 49: 1274-303. [CrossRef]

Triebswetter, Ursula, and Johann Wackerbauer. 2004. Integrated Environmental Innovation in the German Automotive Industry: Policy Drivers and Consequences for Competitiveness. Unpublished manuscript. Available online: http://userpage.fu-berlin.de/ffu/ akumwelt/bc2004/download/triebswetter_wackerbauer_f.pdf (accessed on 5 January 2021).

Triebswetter, Ursula, and Johann Wackerbauer. 2008. Integrated environmental product innovation and impacts on company competitiveness: A case study of the automotive industry in the region of Munich. European Environment 18: 30-44. [CrossRef]

Van Loo, Ellen J., Vincenzina Caputo, Rodolfo M. Nayga Jr., Han-Seok Seo, Baoyue Zhang, and Wim Verbeke. 2015. Sustainability labels on coffee: Consumer preferences, willingness-to-pay and visual attention to attributes. Ecological Economics 118: 215-25. [CrossRef]

Ward, David O., Chrisopher D. Clark, Kimberly L. Jensen, Steven T. Yen, and Clifford S. Russell. 2011. Factors influencing willingnessto-pay for the ENERGY STAR ${ }^{\circledR}$ label. Energy Policy 39: 1450-58. [CrossRef]

Wong, Veronica, William Turner, and Paul Stoneman. 1996. Marketing strategies and market prospects for environmentally-friendly consumer products. British Journal of Management 7: 263-81. [CrossRef]

Zeng, Sai-Xing, Xiang-Hui Meng, Ruo-Chen Zeng, C. M. Tam, Vivian W. Y. Tam, and T. Jin. 2011. How environmental management driving forces affect environmental and economic performance of SMEs: A study in the Northern China district. Journal of Cleaner Production 19: 1426-37. [CrossRef]

Zhang, Dayong, Zhao Rong, and Qiang Ji. 2019. Green innovation and firm performance: Evidence from listed companies in China. Resources, Conservation and Recycling 144: 48-55. [CrossRef]

Zhang, Ting, Sonja Gensler, and Rosanna Garcia. 2011. A Study of the Diffusion of Alternative Fuel Vehicles: An Agent-based Modelling Approach. Journal of Product Innovation Management 28: 152-68. [CrossRef]

Zhou, Haidi, Qiang Wang, and Xiande Zhao. 2020. Corporate social responsibility and innovation: A comparative study. Industrial Management E Data Systems 120: 863-82. [CrossRef] 